\title{
Jesus Christ and Billy the Kid as Archetypes of the Self in American Cinema
}

\author{
Michelangelo Paganopoulos \\ Goldsmiths College \\ University of London
}

\begin{abstract}
This paper combines cultural and anthropological perspectives, focusing on the affinity between the concepts of 'collective consciousness' (Durkheim) and 'collective unconcsciousness' (Jung). It argues that films are the dreams of charismatic auteur directors, who project their prophetic vision to a wider audience, in the Celluloid Church. These mechanically reproduced visions are based on eternal myths and archetypes, which symbolically reflect upon the contemporary industry/society that produces them. In this context, the paper focuses on film depictions of Billy the Kid as an archetype of the Self, with visual references to Jesus' Crucifixion and Lamentation, in order to illustrate the "spiritual" turn inwards Christianity as expressed in the collective consciousness of American culture, from the anti-communist 1950s, and through the spirituality of the 1960s and 1970s to the recent rise of Evangelical Christianity.
\end{abstract}

\section{Introduction}

[1] In recent years, there has been an increasing "revitalised interest" in Jungian psychoanalytical method based on the concept of cinema as a collective experience, especially in the fields of literature and cultural studies, such as "post-Jungian" film analysis. ${ }^{1}$ Hauke and Alister argue that watching a film in a cinema is an experience "set apart" from daily life, "in a dark place dedicated to this purpose ... where psyche can come alive, be experienced and be commented upon." 2 The art of cinema has technologically transformed the mystical luminous experience of rituals into luminous screen images of archetypal heroes and narratives, invested with symbols of mechanically reproduced dreams. ${ }^{3}$ Films are based on collective myths and legends, narrated in a Celluloid Church. Through this medium, the auteur director controls the aesthetical world of the audience's cosmos, taking the role of the charismatic prophet of a whole generation. Through his eyes, the visual metaphors of a film can transform each viewer from within, and at the same time, establish, reproduce, and critically reflect upon the collective consciousness of the viewers' understanding of "society" as a whole, and more specifically, of the film industry that produces them.

[2] In highlighting the affinity between Carl Gustav Jung's concept of "collective unconsciousness" and Emile Durkheim's "collective consciousness," I look into the ideals of friendship, love, and sacrifice of the most famous outcast of all, Jesus, as an archetype of the Christian moral Self. In particular, I focus on the myth of Billy the Kid, in visual correlations to the symbolism of Jesus' crucifixion and resurrection in two films: Arthur Penn's The Left- 
Handed Gun (1958), and Sam Peckinpah's Pat Garrett and Billy the Kid (1973), with comparative references to other films of the time. The correlations I will be drawing of Billy as the Self/Shadow archetype of Jesus, critically reflect on the changes in American culture that took place in the second half of the twentieth century, starting from the anti-communist hysteria of the 1950s, and through the spirituality of the 1960s, to the rise of neofundamentalist Christianity.

\section{The Celluloid Church: Jesus as a Moral Archetype of the Self}

Jung was impressed by what cinema offered in terms of the imagery, narratives and the dynamics of film — both photographically and in the human processes depicted ... cinema offers both a means and a space to witness the psyche-almost literally in projection. Cinema fields deliver a contemporary experience set apart from "daily life"-collectively experienced with others in a dark place dedicated to this purpose. This experience of psyche-inprojection travels further and differently from that offered by the theatre due to the flexibility involved in the photographic medium ... Cinema has the possibility of becoming an imaginal space-a temenos - and by engaging with films a version of active imagination is stimulated which can then engage the unconscious-potentially in as successful a fashion as our conscious attention to dream imagery and other fantasies ... cinema represents a birth of the collective. ${ }^{4}$

[3] From a post-Jungian perspective, cinema can be seen as a modern metaphor of Durkheim's "Church." For Durkheim the concept of the" sacred" formed a unifying system of belief, collectively expressed in rituals, which through "things apart and forbidden" formed the moral order and structural hierarchy of a totemic "society". 5 For both Jung and Durkheim religion was a matter of personal experience, a way to connect the individual to the wider collective, through the luminous experiential concept of "numinous" (Rudolf Otto). ${ }^{6}$ Jung highlights the Self as the source of this collective and impersonal force, which he associates with archaic elements of the "collective unconsciousness." The Self is "a religious mythologem" existing "completely outside the personal sphere." "In Jung, this a priori force is manifested in luminous personal experiences, in which the Ego's conflict with the Archetypes reach the consciousness dialectically, stimulating the individual's psyche.

[4] By contrast, Durkheim's sociological method pointed to Society as a priori, the external force expressed in "collective representations" revealing the "collective consciousness" of the group as a whole. ${ }^{8}$ The a priori conceptions of Self and Society reveal an affinity between Jung's internal concept of "collective unconsciousness" and Durkheim's external "collective consciousness." But while Durkheim's starting point is "society," morally acting upon each individual, Jung's begins with the archaic Self that subconsciously functions from within through dreams and myths. In collective representations, such as rituals and films, the participant audience creatively recognizes the existence and interaction of both inner and outer worlds. In this sense, for Jung the life of Jesus, symbolized by the Christian Mass, is eternal, out of time:

Journal of Religion and Popular Culture

Volume 22(1): Spring 2010 
The Mass is an extramundane and extratemporal act in which Christ is sacrificed and then resurrected in the transformed substances; and the rite of his sacrificial death is not a repetition of the historical event but the original, unique, and eternal act. The experience of the Mass is therefore a participation in the transcendence of life which overcomes all bounds of space and time. It is a moment of eternity in time. ${ }^{9}$

[5] For Jung, such acts of collective transcendence reveal the existence of a deeper archaic "collective unconscious," manifested in "inherited" and "pre-existent archetypes": unconscious projections of collective representations of the human psyche, which, independently from the individual, come to the surface through dreams, visions, myths, fairytales, rituals, and in the arts, as "collective representations." ${ }^{10}$ Jung borrowed the term from Levy-Bruhl, ${ }^{11}$ referring to a deeper esoteric world of "moral, aesthetic, and religious values" of "universally recognized ideals or feeling toned collective ideas." 12 He highlighted five elementary "archetypes" with a "preconscious psychic disposition" that can initiate the creative or destructive forces within us: the Self, its Shadow, the Soul, the Divine Couple, and the Child. These archetypes have three important characteristics: first they are a priori, meaning that they are a natural part of human nature, pre-existing in the psychic of each individual by birth; second, they are elemental in the creation of social life, a "collective unconsciousness," expressed in cosmology, arts, and religion; and third, because archetypes are esoteric, they are also thought to be universal. ${ }^{13}$

[6] Jung's psychoanalytical method is generally based on the resolution of the conflict between who we believe we are, and how we think we are perceived by others-our projection of a Self. He defined the Self as a unitary "whole," a self-projection of a luminous "God-image" (Imago Dei). ${ }^{14}$ Its counterpart is the Shadow, the things we perceive to be foreign, outside our Self, but which in fact still spring out from inside ourselves, but we conveniently project onto others. Conversely, the Shadow has "an emotional nature, a kind of autonomy, and accordingly an obsessive or, better, possessive quality" 15 . In Jung, religion played a vital role in expressing these eternal forces through cosmological symbolism. He illustrated these two contrasting perceptions of who we think we should be, and who we deny we are not, in the images of the Christ and the Antichrist, the former as "the archetype of the self," which is "as good as perfect ... the perfect man who is crucified"16, and Satan as the antithesis, His moral dark counterpart.

[7] The symbolism of Jesus as an archetype of the Self stems from His ambiguous, legendary, marginal life, and unknown origin. His miraculous life was marked by persecution, selfsacrifice, resurrection, and ascension to Heaven. However, Jesus is only an aspect of the archaic Self of "Christ", which is present in everybody a priori, meaning that it pre-exists the historical figure of Jesus, while finding expression through the symbolic life of Jesus.

The life of Christ is understood by the Church, on the one hand, as an historical, and on the other hand, as an eternally existing, mystery. This is especially evident in the sacrifice of the Mass ... Christ lived a concrete, personal, and unique life which, in all essential features, had at the same time 
an archetypal character. This character can be recognized from the numerous connections of the biographical details with world-wide myth-motifs. These undeniable connections are the main reason why it is so difficult for researchers into the life of Jesus to construct from the gospel reports an individual life divested of myth. In the gospel, themselves factual reports, legends, and myths are woven into a whole. ${ }^{17}$

[8] Jung was thus careful to distinguish between "natural symbol" of Christ, and the historical figure associated with the institutionalised "dogma" of the Church. ${ }^{18}$ In a similar manner, the "dogmatic figure of Jesus" excludes his dark earth side, the human one, becoming a moral ideal for imitation. In this context, "God's images change but not God." By separating the two, and by highlighting the exclusion of the Shadow from the image of Christ, Jung argued, "the reality of evil was denied by the Church Fathers," 19 making thus, the important distinction between Jesus the historical person from "Jesus" the symbolic archetype of the "Christ within." Jesus as a "natural archetypal character" is one of the endless manifestations of the archetype of the Self, which in Christianity is defined in the moral terms of sacrifice, humility, sense of justice, and transcendental self-liberation from the material body. However, these are motives to be found in various mythological cosmologies, and in a diversity of practices of sacred systems, which are conceptualized in imitation of the symbolic and historic lives of "charismatic" figures (as in Weber), such as Buddha and Muhammad. In this dualistic way, Jung distinguished between history and mythology, the outer and the inner worlds of human existence. ${ }^{20}$

[9] Jung was also careful to underline that by the "will of God," he does not mean the Christian God. "God," as in the philosophy of Socrates, is a daimonion, that is, "a determining power which comes upon man from outside." ${ }^{21}$ Following the Bible in which "Christ 'cast off his shadow from himself'," Jung argued "the Christian-symbol (of Christ) lacks wholeness in the modern psychological sense, since it does not include ("cast off") the dark side of things but specifically excludes it in the form of a Luciferian opponent," the Antichrist $^{22}$. Within the context of the Imago Dei, Jesus' crucifixion symbolically becomes the "crucifixion of the ego," 23 revealing the illusion of the "self" (as in Buddhism). The moral struggle between what is thought to be Good and Evil goes beyond history, as it takes place inside the Self, through personal moments of transcendental interactions between the archetype that "denotes completeness but is far from being perfect," and the illusionary image of the Self, who we think we should be. This conflict takes place inside the "ego," which consists of "somatic" and "psychic" forces ${ }^{24}$, united through psychosomatic experiences that under particular circumstances can be seen as psychosomatic neurosis. This inner conflict between the Ego and the Self is often the underlying theme of many films.

\section{The Self as the Archetype of Jesus in Cinema}

[10] It is interesting to compare Jung's ideas to Mauss's essay on "the notion of the person" and the "notion of the self" (1938), ${ }^{25}$ in which Durkheim's nephew makes an evolutionary connection between ideas of a "person" and the "self", from the sacred use of masks to the legal constitution of the Roman "person," and through the Christian "moral person", 
exemplified by Jesus, to contemporary psychological ideas of the "self" ${ }^{26}$ Although Jung and Mauss have contrasting perspectives of the idea of the "self", as Jung focused on the individual by taking an archaic, symbolic, and psychological view, while Mauss looked into rituals taking an evolutionary and sociological perspective, Jung referred to Hubert and Mauss's work on the "categories of imagination in defining the collective unconsciousness through Archetypes", ${ }^{27}$ in order to associate the idea of a "self" to masks, religious performances, and cosmological myths, as "collective representations." Both Jung and Mauss, separate the Ego behind the mask (history of the individual) from the Persona represented by the mask (the mythology of the mask). In this context, archetypes change masks, according to the time they are produced. This is illustrated in the collection of essays on "post-Jungian takes on film" by Hauke and Alister (2001), which pays particular attention to the "dynamic nature of symbols," the changes in the meaning and interpretation of a symbol on the basis of the same archaic archetype. ${ }^{28}$

[11] For instance, Pelikan discusses eighteen different images of Jesus in history, including those of Socrates and Martin Luther King, who exemplify the symbolic and moral qualities of the life of Jesus. ${ }^{29}$ What unites the different personas and historical circumstances is the archetype of "Jesus" as the Christian moral person, the protector of the oppressed, who willingly sacrificed Him-Self for the common good. The morality exemplified by the life of Jesus projects the Christian values of social justice and self-sacrifice. These can be also found in the writings of Durkheim: "Egoism has been universally classified among the amoral traits ... If there is such a thing as morality, it must necessarily link man to goals that go beyond the circle of individual interests." 30

[12] The moral ideals of Jesus' life were first luminously illustrated on the big screen in DW Griffith's Intolerance (US 1916), a study of Love and Hate in four different overlapping epochs: the burning of Babylon, St Bartholomew's Day Massacre, a modern everyday drama of social injustice in the US, accompanied by sequences with extracts from the miraculous life of Jesus. The film could be seen as a Jungian study of archetypes: Jesus as the archetype of the Self, Catherine de Medici as the Shadow, the bond between the King and the Queen of Babylon as both a study of the Soul (animus/a) and of the Divine Couple of completeness, and a modern illustration of all the above archetypes within the urban story of the young girl, whose husband is unfairly hunted down, and her Children (hope) are taken away by social services. The film was thought to be a personal redemption for the director's previous long feature, the racist and hateful Birth of a Nation (1912), though it was also criticized for its anti-Semitism.

[13] The same ideals have been reproduced in hundreds of films about, or with reference to, Jesus. Even before Griffith's groundbreaking work, directors such as Zecca, who in 1902 first filmed The Life and Passion of Jesus Christ, adopted stories from the Bible. Subsequently, there appeared the figurative Jesus of the silent From the Manger to the Cross (1912), the pious Jesus in King of Kings (De Mille 1927), the Jesus as the common man in The Greatest Story Ever Told (Stevens 1964), Pasolinis's revolutionary Jesus in Vangelo Secondo Matteo (Italy 1964), the dancing Jesus in Jesus Christ Superstar (1973), the Bollywood Jesus in 
Daya Sagar (India 1979), Scorsese's and Kazantzakis's Last Temptation of Christ (1987) that initiated a serious of protests worldwide, and more recently, The Passion of the Christ (Gibson 2004) in which martyrdom becomes the central theme rather than the teachings of Jesus, provoking a series of protests, this time for its cruel portrayal of the people of Jerusalem. The depictions of Jesus change according to the time and place the film was produced, the funding and the film industry involved in the production and distribution, the targeted audience, and the aims and style of the director. For instance, The Jesus Film Project (1979) was a cheap production funded by evangelicals, which aimed at target audiences to convert them to evangelical Christianity. The film was dubbed into hundreds of languages and distributed for free all over the world, spreading the word of Jesus in the old missionary colonialist manner.

[14] The value of Self-Sacrifice for Justice through the Crucifixion and Resurrection of Jesus has thus been illustrated in numerous films with visual or narrative references to "Jesus" as a portrayal of the Self, using narrative parables taken from Christian iconography as visual metaphors set in contemporary urban settings (as in Intolerance). Some directors, like Christian ascetics, even identify with Jesus. For instance, Pier Paolo Pasolini, the great auteur and maker of several religious films, wrote:

In my fantasies there was expressly the desire to imitate Christ in his sacrifice for others, to be condemned to death and killed although innocent. I saw myself hanging from the Cross, nailed to it. My thighs were scantily covered by a light piece of cloth and a huge crowd was looking at me ... With my arms spread out, my hands and feet nailed, I was utterly defenceless, lost”31

[15] In investigating the intimate relationship between the director and the film itself, Beebe has argued: "The director's role in making a film is already, therefore, not unlike that of the Self in creating dreams." 32 Pasolini made three films with direct references to the life of Jesus: Acattone (1961), Vangelo Secondo Matteo (1964), and Teorema (1968). Accattone is the story of a pimp who pushes a young worker called Stella into prostitution, but in a moment of Jungian "individuation" he falls in love with her, while becoming conscious of his class, realizing that he has to help her and himself to get out of prostitution. Although he tries to change his ways, in the end he returns to his old self, and following a burglary that goes wrong he kills himself in a motor accident. Here the motif of sacrifice for social justice is portrayed through a film that departs from the tradition of neo-realist Italian cinema into the more introspective cinema of Pasolini.

[16] In Vangelo Secondo Matteo (1964), and the controversial Teorema (1968) in which Pasolini posed the question "what if Christ now came to earth?", he further developed his style, using figurative body movement of caricature characters (as in the Brechtian technique of alienation) that were "meant to provoke 'a revolution of the spirit", 33 . Vangelo Secondo Matteo portrayed the life of Jesus from the perspective of Pasolini's political anxieties, first seen in Acattone: a social background of injustice, prostitution, and prejudice. According to the principles of Italian neo-realism, the film was shot on location and with amateur actors, but in Calabria, not in Jerusalem. In this dialectical way (using the Brechtian method of 
alienation, by revealing to the audience the illusion of the production, juxtaposed with Italian neo-realism) Pasolini created a "reality points to the absent ideal within it," 34 making the life of Jesus his protest against social injustice: "The social reformist zeal and anger in Pasolini's Christ came from an indignation with the present. Christ, like Pasolini, was an anti-modern. He was the peasant, obedient son of John XXIII ... hence sacredness became it its expression social and not merely a religious state." ${ }^{35}$ In Pasolini's film-making the Self becomes the director's personal, Marxist, Christian Jesus, with all its contradictions (a Catholic morality juxtaposed with a Marxist socialist spirit), in films that morally highlight socialist communal ideals against the self-interest of modern capitalism.

[17] The search for social justice, exemplified by the conflict of the Individual (Jung) against Society (Durkheim), is a dominant theme in all films with visual metaphors and narrative references to the life of Jesus. Jesus represents the rise of the Individual against injustice. For instance, in Kazan's On the Waterfront (US 1954), the marginal hero, the former boxer Terry Malloy (played by Marlon Brando) fights for the right to work against the corrupted Union leaders. Brando's idealized version of the honest working man takes place through a process of self-realization (most famously when he is talking to his brother in the taxi: "I could have been a contender Charlie! But I'm a bum"). In the end, after he gets beaten by a mob, falling in cruciform position on the ground, he stands on his feet to queue for work despite his injuries. He is resurrected. In comparison to Pasolini's Acattone, On the Waterfront reveals a very different study of the Individual versus Society, and although they are similar in highlighting social injustice and discrimination through the process of self-realization of the hero, the politics and industry that produced the two films are contrasting. Kazan's film, despite its success in the 1950s, has since been criticized for his attack on the Unions, as part of the general anti-communist witch-hunt of Joseph McCarthy.

[18] The search for personal salvation is also the underlying theme in two Canadian productions, Jesus de Montréal (Arcand 1989), and Jesus' Son (Maclean 1999). Both films are set in contemporary times, based on a series of visual and narrative metaphors of the life in the big city with references to the life of Jesus, but from very different perspectives. Arcand's film describes the efforts of a young director called Daniel to stage a play about Jesus Passion against forces pushing him towards artistic compromise. The opposition of the Catholic Church to Daniel's play, his rage against the advertising companies, and finally his sacrifice and resurrection after becoming an organ donor, constitute a sharp satire against the Catholic Church, as the hero's life visually echoes the life of Jesus, most spectacularly on the film poster where he ascends to Heavens by escalator. ${ }^{36}$ Jesus' Son, on the other hand, is a drama about drug addiction and the search for self-redemption through a spiritual and bodily catharsis. The film is based on short stories by Denis Johnson, made in an episodic way in revealing the incoherent life of addicts. The film is a strong moral criticism of drug abuse, but also indirectly challenges those, who in the evangelical spirit of rebirth find resolution in Christ, as if the opium of religion replaces the opium of the body.

[19] Resurrection is a third common motif among films visually referring to the life of Jesus, from the repetitive resurrections of Clint Eastwood in Sergio Leone's Spaghetti trilogy of the 
1970s, to Spielberg's religious science fiction and hugely successful ET (US 1982). Central to resurrection is the ideal of self-sacrifice for the universal good as in On the Waterfront. However, in ET the "universal good" is literal, as the alien's resurrection could be seen in the light of the rise of Scientology. ET is a moral story of tolerance, similar to George Lucas's Star Wars trilogy, "a traditional moral study ... Traditionally, we get them (moral lessons) from the Church, the family, art, and in the modern world we get them from media-from movies." ${ }^{37}$ On the other hand, Leone's spaghetti trilogy is full of Catholic imagery, and its moral theme is rather different: Clint Eastwood's resurrections are apocalyptic, the return of the semi-God hero "No Name" for the Second Judgement, to cleanse the earth from its dirt, the bandits and corrupted officials. While ET offers a "universal" moral example of Christian Love and understanding, Leone's westerns are about divine justice, a theme recently revisited in the post-apocalyptic western The Book of Eli (Albert and Allen Hughes 2010).

[20] In sum, the symbolism of "Jesus" as the moral archetype of the Christian Self is conceptualized in various ways, not only in the films about the life of Jesus, but also in films referring to Jesus either as a secular archetype of the Self (the common man), as in Arcand's film, or in the religious sense of salvation, as in Maclean's film. ${ }^{38}$ In the next part I wish to further examine the motifs of social justice and self-sacrifice through the character of Billy the Kid in two American films, produced almost two decades apart, in order to discuss them as conscious projections of the collective unconscious of American culture as a whole. My aim is to reflect on the politics of the period each film was made, in order to fully appreciate them within their historical and cultural context.

\section{The Left-Handed Gun (Arthur Penn, 1958)}

[21] Arthur Penn's debut film The Left-Handed Gun is an intimate visual study of the legend of Billy the Kid. Penn's first project already featured the aesthetical elements of the style that would make him a world-recognized auteur: his slow camera movements juxtaposed with sudden explosions and shifts in mood, light, and rhythm, psychological close ups, elliptical narrative, gestural acting style, and highly ironic content, immediately distinguished him in the Hollywood industry as a unique artist. His films are personal takes on the tension between Individual and Society, a central motif that he builds on the character of the Outcast, most famously depicted in The Miracle Worker (1962), and in Bonnie and Clyde (1967). In an interview, Penn explained:

What I am trying to say through the figure of the outcast is that society has its mirror in its outcasts. A society would be wise to pay attention to the people who do not belong if it wants to find out what its configuration is, and where it's failing 39

[22] Billy the Kid, aka William Bonner, is arguably the most famous outcast of American mythology. He was born in the midst of the American Civil War (1859-1861) in New York as Henry McCarthy, the son of an Irish immigrant. As the legend goes, his mother never told him who his father was. In 1870, Henry's family is traced to Winchita Kansas, a cow town, but because of his mother's tuberculosis they moved to New Mexico, famous for its silver, 
and the good weather. In March 1873, Catherine McCarthy married her second husband Billy Antrim at Santa Fe, on their way to the promised land of Silver City. From there, the legend begins, Billy forming his gang, shooting the general Amnesty down, and being killed by his best friend Pat Garrett with a shot at his back.

[23] In the film, Billy works in the ranch of Tunstall, an English immigrant, who is a fatherfigure to him. After Tunstall is murdered by men working for the local authority, Billy and his gang begin their crusade against the general Amnesty, which they believe supports the interests of the elite, while hiding the social inequalities against the unarmed, peasant, and local population. However, Billy's crusade results in more deaths, illustrated remarkably by the burning of the house of McSween, during which the wife of the family desperate wonders "where is the law?" In Penn's film, the real victims are the farmers, while Billy (Paul Newman) is not portrayed as the legendary hero, but as a naive boy in search for revenge. Just like Jesus, Billy is a constant traveller, hiding among the peasant population because he is persecuted by the authorities. He is about thirty years old, and rides his horse in a posture that imitates Jesus' riding of the donkey, bending forward, moving slowly, and wearing a white robe, an image echoing De Mille's Jesus in King of Kings (1927). Furthermore, he is resurrected (after the newspapers report his "death" in the fire of the house of McSween), and is finally killed by Pat Garrett (John Dehner). Billy anticipates his destiny, as he walks to his death carrying an empty gun. But unlike Jesus, during his life Billy's preached with a loaded gun. His actions are misguided by his beliefs: he thinks he fights for the rights of immigrants and Mexicans, and that he is the moral law; he has the illusion that he is the One who will bring divine justice to the world, when in fact this is nothing but his Ego, as the sequence below shows:

[24] Billy is thought to have died in the fire but he is hiding in the house of Celsa (Lita Milan) and Saval (Martin Garralaga), a Mexican peasant couple. There is an erotic tension between the Celsa and Billy. He shows her a piece of newspaper. He can't read, but he pretends he does.

Billy: "Have you seen that?"

Celsa: "What does it say?"

Billy: "Outlaw youth dead."

Celsa: "Keep it as a souvenir."

Billy: "I ain't dead no more. I come Awake!"

He stretches his left hand. In Christian iconography this is the typical image of Jesus stretching his right hand performing a miracle. In the film, Billy stretches his left hand.

Celsa: "No Billy! Don't go after them."

Billy: "They had me dead. That Amnesty! That's for them ... and they walk around unburied. They put diamonds in my eyes!" 
Celsa: "stop it! You are shaking like a pony. You'll catch a cold."

Billy: "No. I'll get you fire."

He grasps the handle of the cold oven and in a dramatic second builds up a strong fire, lighting up the whole frame, a cinematic miracle of Light and Heat. The girl looks astonished.

Billy: "I got it back. My hand, my arm. And no one ever will take it away from me! I have come to Life!"

Celsa: "You got fever"

Billy: "No. I can't stop now! No more stops."

Celsa: "I have to go back inside."

Billy: "Go! Go!"

Celsa: "stay here. They'll kill you."

Billy: “They've been killing me. Now I don't wait. I go first."

Celsa: "What are you going to do?"

Billy: "I'm gonna run, I'm gonna hide, I'll go wherever I want, I do what I want."

Billy looks intensively into Celsa's eyes.

Celsa: "Don't Billy. Don't do that to me. Don't look at me."

Billy: "I want you ... with me."

Celsa: "No! Stay! Don"t die Billy!"

Billy: (Raises his left hand imitating Jesus posture) "With you! With you!"

He approaches her. She feels threatened. He slowly grabs her. He puts his arms around her covering her face. Close-up to the two faces coming closer and closer to each other.

Celsa: "No! No! No!"

He kisses her passionately on the lips. Fade out to fireworks.

[25] The above powerful sequence is constructed on a double world, similar to the Jungian world of inner and outer realities. The inner world is expressed through the narrative through the violent behaviour of Billy, which morally contradicts his outer appearance, masterfully visualized by the director in imitation of Christian iconography. In Penn's film lighting becomes the means for visualizing the ideal luminous Self in moments of self-realization, as in the above sequence following Billy's "resurrection." Respectively, for Jung "lighting signifies a sudden, unexpected, and overpowering change of psychic condition." the facial expressions in close up and the words of the heroes betray Billy's dark side, the 
Shadow to what appears to be the legendary Billy the Kid. The contrast between Light and Darkness visually projects the inner conflict in the hero's soul, a process of "individuation" in which Billy, in his head, becomes "an in-dividual, that is, a separate indivisible unity or 'whole'." 41 Jungian psychology is a process of self-realization, an unconscious process that comes to the conscious surface through personal moments of transcendental interactions in which "every living thing becomes what it was destined to become from the beginning." called this process "individuation," which "can be realized only through a relation to a partner ... of the opposite sex", 43 in Penn's film represented by Celsa.

[26] However, conveniently to the Western genre, this is another portrayal of women as passive, falling into the hands of gunmen. Billy does not love the girl, but what she represents in his own eyes: the traditional and static "morality of stillness in a nature morte" of the old West, ${ }^{44}$ which at the time of Billy was threatened by the ever-changing modernity, symbolized by the introduction of the railway, and the political hypocrisy of the Amnesty. But in trying to help the others, he only helps himself. His character is the exact opposite to the moral stability and conservatism of the prairies, represented by Pat Garrett. Billy acts forcefully against Celsa and the landscape in the same way as he shoots his enemies. He does not waste time staring at them. He quickly shoots them down without any moral restrain. He takes all he likes, the young modern rebel of a male-dominated cinema. Billy as the erotic object who challenged the ethics of his time was the subject of Howard Hughes's The Outlaw (1943/1950): the image of "Billy's lithe body" challenged "the supposedly Western emphasis on physical tautness and self-control." 45

[27] In the sequence above, the excessive Shadow of Billy is revealed underneath his ideal Self, the protector of the poor. In a parallel irony, he believes in a love that is not there, for the girl loves the symbol, not the man. The visual idealisation of Billy as a kind of Jesus, in a complementary contrast to his egotistical sexual intentions, ironically shows him thinking that he has just realized his "destiny" (in Jung's terms "fate" is the aspect of the unconscious that never becomes conscious to us). Celsa is confused, as she loves the ideal image of Billy, but not Billy's dark side that has no respect for the hospitality offered to him. While he thinks she represents his anima, the moment of self-realization is nothing but his ego taking control, as he forces himself towards Celsa, without her full acceptance.

[28] Billy's second self-illusion is in his search for a father figure. Following the death of his mentor Tunstall, Billy turned to Pat Garrett as a kind of a father figure. Just like the Jewish priests of Jesus' time, Pat Garrett believes in traditional values, family and order, but at the same time he has a sense of justice in him, which is a quality that Billy admires. Garrett changes his attitude towards Billy, when the latter and his gang spoil Garrett's wedding by shooting more deputies down. Garrett never forgives Billy for that. "You promised" he bitterly protests. Billy responds with a careless smile. Their conflict is inevitable as they represent two contrasting understandings of the morality of the landscape: Billy as the hard raised immigrant who wants to free it from social injustice, and Garrett, the traditionalist who wants to marry it. 
[29] Billy's biggest illusion is that he thinks he can change the world, similar to the symbolic life of Jesus. "You are not Him! You are not Him" shouts the disillusioned biographer that follows Billy to record his "miraculous" works with the gun. The moment of true selfrealization approaches when Celsa's husband learns about her erotic relationship with Billy. Billy is no longer wanted. For the first time, guilt rises on his face. As he walks unarmed outside the house, Garrett shoots him. Billy falls on the ground in a crucified position, illustrating Jung's observation: "the descent into the depths always seems to precede the ascent." 46 Billy's "crucifixion" is witnessed by Celsa. The image of her in the arms of Garrett, and the gestural acting in the scene, bring strongly in mind the image of Mary in the arms of John in the Christian imagery of the Crucifixion and the Lamentation of the Virgin Mary-such as the famous Byzantine icon of the Church of Nerezi (near Skopje) dated to $1164 .^{47} \mathrm{~A}$ further close-up on Celsa's face makes another visual reference, this time to the miraculous painting of the Virgin of Guadalupe, Mexico. ${ }^{48}$ In this visually religious context, Billy's "sacrifice" brings an immediate catharsis, as for the first time Garrett's strict face softens, and he regrets the shooting: "I couldn't see," are Garrett's last words, revealing the ambiguity that runs throughout the film regarding Billy's character: could he not see the naivety of the boy lying dead in front him (the moral narrative of the story is violence brings violence), or could he not see the sacrifice of Billy the Kid for social justice in imitation of Jesus ("the true Passover Lamb who takes away the sins of the world and by whose blood we are reconciled to the Father" $\left.{ }^{\prime \prime}\right)$ ?

[30] But as there are no real miracles, there is only Billy's trickery with the gun; likewise, there is no real sacrifice and resurrection, only the hype of the newspapers. From a Jungian perspective, Billy's final "sacrifice" is a personal catharsis from the abyss he has created for himself: "It is often tragedy to see how blatantly a man bungles his own life and the lives of others, yet remaining totally incapable of seeing how much the whole originates in himself," Jung writes. ${ }^{50}$ Despite the Christian imagery, critiques have rightly claimed that this is not a "Christian" parable. ${ }^{51}$ In this context, the film is primarily a critique of the myth of Billy, and through it of the myth of Jesus, as the visual portrayal and gestures of Billy in the tradition of Jesus offer an ironic commentary on the belief in Jesus as the Saviour.

[31] On a political level, Billy's Left Hand is not only a sign of his anti-heroic nature, but could be seen as a reference to communist idealism. The film was produced in Hollywood at the time of the Cold War, alongside anti-communist films, such as Sam Fuller's Pick Up on South Street (1953). These films reveal the climate of anti-communist collective hysteria that was created by General McCarthy's false accusations, prosecutions, and distrust. Robert Hertz, in his early study of religious polarity (1909), identified morality and enlightening strength to the symbolisms of the Right Hand, in opposition to the amorality of the Left Hand and fear of darkness. ${ }^{52}$ In The Left Handed Gun, communist ideals of sharing, and equality are destroyed by Billy's own violent nature. Thus, the film does not constitute a parable about Jesus, but about the ideals of communist and Christian thought. Billy naively believes in Love, Friendship, and Justice, but none of these ideals survive in the Cold War. Conversely, Myth is juxtaposed with History, and ideals for social justice and equality against the reality of the Civil War. 


\section{Pat Garrett and Billy the Kid (Sam Peckinpah, 1973)}

[32] The juxtaposition of Myth and History is also the central motif in Sam Peckinpah's depiction of Billy's legend, in his Pat Garrett and Billy the Kid (1973). Through the Civil War of Billy's time, Peckinpah masterfully reflects upon the Vietnam War of his time. Furthermore, Peckinpah's portrayal of Billy emphasizes the resistance against the corrupted Authorities, similar to other films of the time, such as Sydney Lumet's Dog Day Afternoon (1975), as both films are critical of the flowery 1960s, in the light of the corrupted and brutal 1970s, with the Vietnam War and the Watergate scandal. Through the legend of Billy, Peckinpah directly reflects upon the changes in the history of his time, the corruption of Nixon's office, and a pointless war, which disillusioned a whole generation, and left naked the collective values of the cultural revolution of the 1960s: the belief in social equality, sexual and spiritual freedom, friendship, and active resistance to the authorities.

[33] The opening sequence of Pat Garrett and Billy the Kid is constructed on a wonderful parallel editing of black and white shots, depicting the death of Pat Garrett at the hands of fellow criminals of the legend of the Kid in1909, against a set of colourful shots of the lost past (1881) that show Billy and Pat with competing each other in shooting at a dead chicken's head. The director makes a masterful juxtaposition between History and Mythology: the moody black and white shots of Garrett's death have a documentary quality, while the shots of the past are full of nostalgia, light, colour, and honest friendship. The film continues in colour, taking us into the myth, but in the vivid style of the 1970s. The film is a nostalgic take of Billy's myth, symbolizing the end of the Old West, a theme first chosen by Pechinpah in his earlier western Junior Bonner (1972).

[34] But unlike Penn's moral film (violence brings violence), Peckinpah identifies with Billy. The most famous story coming out of the making of the film is that Peckinpah, and the protagonist Kris Kristofferson (Billy), were constantly drunk throughout the shooting (probably on drugs too), identifying themselves with the hero's drunken haze, and resistance to the Authority through the pleasures and pains of the fleshy spirit. The characters of Billy and Pat Garrett (James Coburn) are also opposite to Penn's version. While in Penn's film, Billy is an uneducated struggling young man of his time, well shaved and clean, in Peckinpah's version he has long hair, he is not shaved, he often walks half-naked among young women, and he can speak Spanish to the Mexicans. Billy, dressed in white, symbolizes the spirit of the 1960s. His constant smile, reassurance of his youth, determinism, and individual pleasure in celebrating communal life, show an amoral return to the value of community.

[35] The film has a few visual references to Christian symbolism, but enriched with heavy irony. For instance, Billy's gang poses as if they are his disciples. One of them is called Alias, and during the film takes the role of Judas betraying Billy to Garrett. Alias is played by Bob Dylan, who wrote the soundtrack of the film. Back in 1966 in Manchester, Dylan was called "Judas!" by a large number of his folk audience, because he put down his acoustic guitar for the electric sound of Like A Rollin' Stone. Dylan had become the "traitor" to a whole generation, a modern Judas to the anti-war movement because of his own 
individualism and creativity. In the film, he represents reality, the end of the time of the legend and the beginning of history, symbolizing the end of the spiritual 1960s and beginning of the war-fuelled 1970s. At the same time, the name "Judas" offers a slight but sharp ironic comment against the Christian dogma, because while in many respects Billy lives in imitation of Jesus, he uses indiscriminate violence as the means of preaching Love.

[36] On the other hand, Pat Gerrett is not the traditional well-shaved, clean-cut Sheriff, who gradually changes his attitude towards the recklessness of Billy as in The Left Handed Gun. In Peckinpah's film, Garrett enjoys life and the sun, group sex, nonstop drinking, and travelling. The difference from Billy is that he decides to represent the Authority, dressed in black leather, and everything the concept of "authority" represented in the 1970s: corrupt power. For instance, "women are of use to Garrett to bolster his butch behaviour. He takes on every prostitute in a bordello, having them all locked up afterwards, as a final assertion of his power over them." ${ }^{53}$ Garrett's control is manifested in the final sequence of the film portraying the death of Billy, as he waits for Billy to have sex with a beautiful Mexican prostitute in his bordello, before shooting him. In this cruel way, Peckinpah challenges the concept of Authority in itself as hypocritical, the means to gain power and imprison Freedom, and a way to criminalize the youth represented by Billy and the Mexican girls. The heroic motif of fighting the hypocrisy of the established authority characterizes the lives of all "charismatic prophets" (as in Weber), including Jesus who fought the hypocrisy of the priests of the Temple. It is a motif that underlines all depictions of Billy, as a kind of the "real" American who deals his business in a direct way, with his gun.

[37] Peckinpah thinks of the general Amnesty offered by the government in the same terms as Billy does: it is hypocrisy, the means to reinforce the established status quo. After another rapid gunfight between Garrett's deputies and Billy's gang, the pace of the editing slows down, and the above song slowly fades in. A fatally injured deputy walks slowly towards the sunset, towards his end. After shooting down a couple of members of Billy's gang, his wife faithfully runs behind her man. In a dramatic close-up, she smiles at him. He returns the smile with the reassurance that they will meet again soon, in Heaven. He falls on his knees, and then on the ground. A crane-shot gives a long shot bird's eye point of view on the scene in juxtaposition to the dramatic close-up. Fade out. Song accompanying the sequence:

Mama take this badge of me

I can't use it anymore

It's getting dark, too dark to see

Feels like I'm knockin' on Heaven's door

Mama put my guns in the ground

I can't shoot them anymore

That cold black cloud is comin' on down

Feels like I'm knockin' on Heaven's door

(Bob Dylan, Knocking On Heavens Door, 1973, film soundtrack) 
[38] In this elegiac scene of Life and Death, Peckinpah offers a sublime portrayal of humanity, while he unconditionally accepts violence as a part of - the Shadow-human nature. The unifying spirituality of the experience of Death is juxtaposed with the egotistic power of the Gun. In investigating the co-existance of internal Love and external Violence, the film becomes a poetic critical outlook of the 1970s, setting spirituality against the reality of brutal violence. This juxtaposition is the central motif in a number films of the time, such as Badlands (1973), the sublime debut of Terrence Malick, with Martin Sheen as Billy and Sissy Spacek as Holly, which undermined the spiritual ideal of returning to nature as the means of discovering Freedom, against rapid and ultra-realistic shots of violence. In comparing these films to the treatment of the legend of Billy the Kid by Arthur Penn, we see that while they all reveal the illusion of Love and Friendship, they adopt them according to their respective times: Penn questions these ideals in the context of the Cold War, while Peckinpah and Malick challenge the value of Free Love in the context of the Vietnam War:

Sequence of Billy's Escape

[39] Billy is caught, jailed, and waiting to be hanged. He is tied up on a chair with two deputies guarding him. One is young and kind, but the other is aggressive, and speaks as if he preaches the Gospel in the Evangelical spirit of repentance. The Christian deputy catches Billy by the neck pushing him on his knees under his long shotgun. "REPENT! Repent for your sins!” he shouts at Billy's face. He is ready to shoot Billy, when the young deputy (like a good cop/bad cop) stops him from pulling the trigger. The Christian Sheriff walks out of the room to take some air and relax. He enjoys watching the kids playfully swinging on the rope of the central platform that was built for Billy to be executed upon. Meanwhile, Billy manages to untie himself and shoots the young deputy, who had just saved his life, in the back. Nothing stands in the way of Billy's sense of personal freedom. Billy walks out onto the balcony of the jail. In terms of framework, he is positioned at the right top of the screen and in juxtaposition to the left lower part of the screen, where the Christian Sheriff is looking for his gun, after hearing the shooting inside the jail and realizing that the Devil Billy is free again. The sun covers Billy's figure looking downwards to the Sheriff from a position of divine dominance. In juxtaposition, the Sheriff, looks upwards trying to see Billy, but he is blinded by the sun: the scene indirectly and ironically refers to the Evangelical motif "I was blind but now I can see," by visually turning it around: the weak Christian Sheriff is in vain looking for the Shadow (Jung) of the Devil Billy. Billy says before shooting him down:

Billy: "How's Jesus look to you now, Bob?" Bang.

[40] Through this drunken-bullet-fuelled juxtaposition, Peckinpah represents Billy in visual references to the Shadow of Jesus as an ironic youthful comment about Christianity and the state represented by the Christian Sheriff, making a visual reference to the violent Shadow of Christianity itself. The dark side of Christianity was sublimely portrayed in The Night of the Hunter (Charles Laughton 1955), in which the villain anti-hero is a Preacher (Robert Mitchum) with a tattoo inscribing the word "Love" on the fingers of his right hand that carries the Bible, and "Hate" on his left hand that carries the Gun. He is a murderer, not unlike some preaching politicians of today. Nowadays, with the privatisation of the American 
army, the violence of the mythical Wild West has become the standard American policy exported in the world: from Vietnam to Iraq. In the above scene, in the spirit of Laughton, the great auteur Peckinpah achieves in making an aesthetic prophetic reference of a coming dark future ("That long black clouds are coming on down"), a prophetic connection between the New Age Movements of the 1960s and the political rise of the Evangelical Christians in the 1970s up to the presidency of the Texan Evangelist (former) President George W. Bush. If I could transfer Billy's above rhetorical question to the dead masses of Iraq it would indeed sound like Bush:

\section{"How's Jesus look to you now, Iraq (Vietnam)?"}

[41] The spirit of Billy still lives in the Bible Belt, the deserts of Texas and New Mexico. Billy embodies the kind of "Love" that these people preach, the love for personal freedom embodied on the symbolism of the "right to own a gun," despite massacres in schools, ${ }^{54}$ the criminalization of teenagers, the institutionalisation of war as a kind of holiday vacation, the fascism of the media, and the disappearance of thousands "illegal" immigrants every year (as if they are "illegal" human beings). This is the land of the "free" salvation in spiritualized Evangelical Christianity. ${ }^{55}$ But this turn to Evangelical Christianity also gave birth to Shadow sects, such as "The Children of God" of San Diego, Texas, whose leader Davis Berg institutionalised child abuse according to his "Law of Love of Jesus". 56 "Charismatic prophets" such as David Berg, or the Reverend Jones of the suicidal sect of Jonestown in the 1970s, following in Billy's footsteps, created a "persecution complex" among their own followers, ${ }^{57}$ which in their minds justified the use of violence against the authority of the "corrupted" FBI (as if there is actually a secret agency that is not corrupted). Nowadays, this collective "persecution complex" has become the standard policy regarding the Islamic heaven of petrol. The "persecution complex" is the illusion that neo-conservative politics of fear are based on, the fear of insecurity. It is the place, where neo-conservatives find a safe home from the "terrorist threat." Ironically, it is the same place where terrorists find the spirit of "resistance."

[42] Billy the Kid is no longer a menace, but the individualist spirit of our times. He is no longer the immigrant who fought for social justice, the free spirit of the 1960s, or the outcast hero. The myth of Billy today does not belong to the hard working immigrants, the contemporary "Mexicans" of our time, as it used to be. On the contrary, in the name of Democracy and Freedom, which Billy has shot at the back in a number of screenings in the past, the Kid becomes the symbol of the conquest of the Wild East, with new Billies appearing and re-appearing in the media, from Iran to the US; and the shooting begins. As the Officer, in John Ford's classic The Man who Shot Liberty Valance (1962), says: "when the legend becomes fact, keep the legend.

\section{Notes}


${ }^{1}$ Christopher Hauke and Ian Alister, Introduction to Jung and Film: Post-Jungian Takes on the Moving Image (New York: Brunner-Routledge, 2001) 1-13. See also: John Fitch, "Archetypes on the American Screen: Heroes and Anti-heroes", Journal of Religion and Popular Culture 7 (Summer 2004) http://www.usask.ca/relst/jrpc/art7-archetypes.html (accessed February 13 2010). Anton K. Kozlovic, "Superman as Christ-Figure: The American Pop Culture Movie Messiah" Journal of Religion and Film 6, no1 (April 2002) http://www.unomaha.edu/jrf/superman.htm (accessed February 13 2010).

${ }^{2}$ Christopher Hauke and Ian Alister, Jung and Film: Post-Jungian Takes on the Moving Image (New York: Brunner-Routledge, 2001), 2.

${ }^{3}$ In The Sacred Cinema of Andrei Tarkovski, Jeremy Mark Robinson highlights that Tarkovski extensively uses images of water and rain to portray the spiritual world of his heroes (Kent: Crescent Moon, 2007) 78. This follows Jung's conviction that "water is the commonest symbol for the unconscious", in The Collected Works of CG Jung Vol.9, Part I (London: Routledge and Kegan Paul, 1968), 18.

${ }^{4}$ Christopher Hauke, and Ian Alister, Jung and Film (New York: Brunner-Routledge, 2001), $1-3$

${ }^{5}$ Emile Durkheim, "The Elementary Forms of the Religious Life" in Reader in Comparative Religion, ed. William A. Lessa, and Evon Z. Vogt (New York: Harper Collins, 1979), 29.

${ }^{6}$ Rudolf Otto, The Idea of the Holy (London: Oxford UP, 1958), 5-11.

${ }^{7}$ Carl G. Jung, CW Vol. 9 Part II, 30.

${ }^{8}$ Durkheim's sociological method has been severely criticized for its a-historicity (Stanley J. Tambiah, Magic, Science, Religion, and the Scope of Rationality (Cambridge: Cambridge UP, 1990, 50-51), emphasis on a homogeneous and unifying concept of a 'sacred" (Michael J. Sallnow, "Communitas Reconsidered" MAN Vol. 16, 1981), and his a priori concept of 'society" denies individual agency (Marilyn Strathern "1989: The Concept of Society is Theoretically Obsolete: The Presentations: For the Motion (I).” In Key Debates In Anthropology. Ed. Tim Ingold (London: Routledge, 1996, 60-66). Durkheim has been contrasted to Weber's emphasis on individual action ("charisma") as the means of making history: "Individualist thought (or methodological individualism) is often associated to Max Weber, whereas collectivist thought (or methodological collectivism) is associated with Marx and Durkheim" (Thomas H. Eriksen, Small Places, Large Issues. London: Pluto, 2001, 84). My argument is that although they take different perspectives, Jung, Weber, and Durkheim, write on the same theme: the relationship of the Individual to Society.

${ }^{9}$ Carl G. Jung, CW Vol. 9 Part I,118.

${ }^{10}$ Carl G. Jung, CW Vol.9, Part I. (London: Routledge and Kegan Paul, 1968), 41-43, and 5963. 
${ }^{11}$ The term was first use in Levy-Bruhl's How Natives Think (1910).

${ }^{12}$ Carl G. Jung, The Collected Works of C. G. Jung Volume 9, Part II: AION (London: Routledge and Kegan Paul, 1968), 29.

${ }^{13}$ However, unlike Durkheim, Jung was adamant that History begins with the individual: "In our most private and most subjective lives we are not only the passive witnesses of our age, and its sufferers, but also its makers. We make our own epoch" (Jung 1934). In this context Jungian psychology is also connected to the making of history, as in Weber's concept of "charisma," referring to the individual " "natural leaders' in times of psychic, physical, economic, ethical, religious, political distress." Max Weber, Max Weber: On Charisma and Institution Building, ed. Shmuel N. Eisenstadt (Chicago: University of Chicago Press, 1968), 18.

${ }^{14}$ Carl G. Jung, CW Vol.9 Part II, 31 and 37.

${ }^{15}$ Carl G. Jung, CW Vol. 9 Part II, 8-11.

${ }^{16}$ Carl G. Jung, CW Vol. 9 Part II, 69.

${ }^{17}$ Carl G. Jung, CW Vol.11. Psychology and Religion: West and East (London: Routledge and Kegan Paul, 1969), 88.

${ }^{18}$ For instance, in his Psychology and Religion (1938), he argued that the "natural quaternity symbol" is universal" as he considered the number Four to be the "natural" cosmological number of our understanding of the world (four elements, four directions, four seasons, four Hindu castes, four Gospels, four colours). However, within the Christian dogmatic tradition, the number Four is reduced to the Holy Trinity, which excludes the Mother of God who "represents the earth," underlying the institutionalised theological association of women with desire (Carl G. Jung, CW Vol.11, 87).

${ }^{19}$ Carl G. Jung, CW Vol.9 Part II, 49.

${ }^{20}$ In this context, Levi-Strauss highlighted a "gap" between history of the past and politics of the present: "in our own societies, history has replaced mythology and fulfils the same function ... to ensure ... the future will remain faithful to the present and to the past. For us, however, the future should be always different ... depending of course on our political preferences" in Myth and Meaning (London: Routledge, 1980), 43.

${ }^{21}$ Carl G. Jung, CW Vol.9 Part II, 27.

${ }^{22}$ Carl G. Jung, CW Vol.9 Part II, 41-45.

In addition to the archetypes of the Self (Christ) and the Shadow (Antichrist) Jung referred to three more archetypes: the Soul (the male animus and female anima within Jesus), the syzygy (Divine Couple) as the ideal of complete wholeness and holiness, religiously expressed in the 
marriage of Christ to the Church, and the "Child," the promise of transcendence symbolized by the birth of Christ.

${ }^{23}$ Carl G. Jung, CW Vol.9 Part II, 44.

${ }^{24}$ Carl G. Jung, CW Vol. 9 Part II, 3.

${ }^{25}$ Marcel Mauss, "A Category of the Human Mind: the notion of person; the notion of self" in The Category of Person, ed. Michael Carrithers, Steven Collins, and Steven Lukes (Cambridge: Cambridge UP, 1985) 1-25.

${ }^{26}$ In this context, Jonathan Parry has argued that the concept of "self-interest" is a product of the capitalist "ideology of the pure gift", in "The Gift, the Indian Gift and the "Indian Gift", MAN 21 (1986), 469.

${ }^{27}$ Carl G. Jung, CW Vol.9 Part I, 43.

${ }^{28}$ Christopher Hauke and Ian Alister, Jung and Film (New York: Brunner-Routledge 2001) 6.

${ }^{29}$ Jaroslav Pelikan, Jesus through the Centuries: His Place in the History of Culture (London: Yale UP, 1985).

${ }^{30}$ Emile Durkheim, On Morality and Society, ed. Robert N. Bellah (Chicago: University of Chicago, 1973), 65.

${ }^{31}$ Pier Paolo Pasolini quoted by Sam Rohdie, The Passion of Pier Paolo Pasolini (London: BFI, 1995) 68.

32 John Beebe, "The Anima in Film" in Jung and Film: Post-Jungian Takes on the Moving Image, ed. Christopher Hauke and Ian Alister (New York: Brunner-Routledge, 2001), 208.

${ }^{33}$ Sam Rohdie, The Passion of Pier Paolo Pasolini (London: BFI, 1995), 159.

${ }^{34}$ Sam Rohdie, 60.

${ }^{35}$ Sam Rohdie, 161.

${ }^{36}$ Richard Walsh, "The Passion as Horror Film: St Mel of the Cross," Journal of Religion and Popular Culture 20, (Fall 2008), http://www.usask.ca/relst/jrpc/art20-

passionashorror.html (accessed 13 February 2010).

${ }^{37}$ George Lukas quoted by John C. McDowell in The Gospel According to Star Wars: Faith, Hope, and the Force (Louisville and London: Westminster John Knox Press, 2007), XVII.

${ }^{38}$ Tim Parrish, “Jesus on the Mainline: Lou Reed and Denis Johnson's Jesus' Son”, Journal of Religion and Popular Culture 7, (Summer 2004), http://www.usask.ca/relst/jrpc/art7jesusson.html (accessed 13 February 2010). 
${ }^{39}$ Arthur Penn cited in World Film Directors Volume 2, 1945-1985, ed. John Wakeman, (New York: HW Wilson, 1987).

${ }^{40}$ Carl G. Jung, CW Vol.9 Part I, 295.

${ }^{41}$ Carl G. Jung, CW Vol.9 Part I, 275.

${ }^{42}$ Carl G. Jung, CW Vol.11, 87.

${ }^{43}$ Carl G. Jung, CW Vol.11, 22.

${ }^{44}$ Lee Clark Mitchell, Westerns: Making the Man in Fiction and Film (Chicago and London: The University of Chicago Press, 1996) 35-40.

${ }^{45}$ Billy as the erotic object who challenged the ethics of his time was the subject of Howard Hughes's The Outlaw (1943/1950). Lee Clark Mitchell argued that the image of "Billy's lithe body" challenged "the supposedly Western emphasis on physical tautness and self-control." (Chicago and London: The University of Chicago Press), 157.

${ }^{46}$ Carl G. Jung, CW Vol.9, Part I, 19.

${ }^{47}$ Andre Grabar, Byzantine Painting (Geneva: Alberta Skira, 1953), 143.

${ }^{48}$ Victor and Edith Turner, Image and Pilgrimage in Christian Culture (Oxford: Basil Blackwell 1978).

${ }^{49}$ Robert J. Daly, Christian Sacrifice: The Judaeo-Christian Background Before Origen (Washington: The Catholic University of America Press, 1978), 3.

${ }^{50}$ Carl G. Jung, CW Vol.9 Part II, 10.

${ }^{51}$ Robin Wood, Arthur Penn (London : Studio Vista, 1967), 27.

${ }^{52}$ Robert Hertz, "The Pre-eminence of the Right Hand: A Study in Religious Polarity" in Right and Left: Essays in Dual Symbolic Classification, ed. Rodney Needham (Chicago: University of Chicago Press, 1973), 3-31.

${ }^{53}$ Terence Butler Crucified Heroes: The Films of Sam Peckinpah (London: Gordon Fraser, 1979), 88.

54 Watch Michael Moore's Bowling for Columbine (2003).

${ }^{55}$ In the 1990s the Western genre became even more a religious genre, shamelessly exporting Evangelicalism. This is a following sequence from Stolen Women (Jerry London, 1997):

Scene: A carriage with two brave white sisters is surrounded by a bunch of English speaking "barbaric" Indians. The leader of the pack is ready to shoot at the girls with his shotgun, when in a melodramatic close-up he notices the Holy Book in the hands of the elder sister. A sudden white flash takes place, echoing the Biblical flash that 
made St Paul "to see" in the desert, as well as the life of George Bush, an ex-alcoholic turned to Jesus. The Indian miraculously puts his shotgun down. The Bible that the elder sister (Janine Turner) grasps in her hands saves her life (the Bible is life). The white women are taken to the exotic Indian village to start with their mission: to teach the Holy Book to those "barbarians."

56 Watch "Cult Killer: The Rick Rodriguez Story" in Cutting Edge documentary series, Channel 4, UK (21/8/06).

${ }^{57}$ John R. Hall, “Apocalypse at Jonestown” in Magic, Witchcraft, and Religion $4^{\text {th }}$ Edition, ed. Arthur C. Lehmann and James E. Myers (California: Mayfield, 1997) 361-2.

\section{References}

Beebe, John. 2001. The Anima in Film. In Jung and Film: Post-Jungian Takes on the Moving Image, ed. Christopher Hauke, and Ian Alister, 208-225. New York: Brunner-Routledge.

Butler, Terence. 1979. Crucified Heroes: The Films of Sam Peckinpah. London: Gordon Fraser.

Daly, Robert J. 1978. Christian Sacrifice: The Judaeo-Christian Background before Origen. Washington: The Catholic University of America Press.

Durkheim, Emile. 1973. On Morality and Society. Ed. Rober N. Bellah. Chicago: University of Chicago.

Durkheim, Emile. 1979. The Elementary Forms of the Religious Life. In Reader in Comparative Religion $4^{\text {th }}$ Edition, ed. William A. Lessa and Evon Z. Vogt, 27-35. New York: Harper Collins.

Fitch, John, III, Johnson C. Smith. 2004. Archetypes on the American Screen: Heroes and Anti-heroes. Journal of Religion and Popular Culture 7 (Summer 2004), http://www.usask.ca/relst/jrpc/art7-archetypes.html (accessed February 13 2010).

Grabar, Andre. 1953. Byzantine Painting. Geneva: Alberta Skira.

Hall, John R. 1997. Apocalypse at Jonestown. In Magic, Witchcraft, and Religion $4^{\text {th }}$ Edition, ed. Arthur C. Lehman and James E. Myers, 353-364. California, London, and Toronto: Mayfield.

Hauke, Christopher, and Ian Alister. 2001. Jung and Film: Post-Jungian Takes on the Moving Image. New York: Brunner-Routledge.

Hertz, Robert. 1973. The Pre-eminence of the Right Hand: A Study in Religious Polarity. In Right and Left: Essays in Dual Symbolic Classification, ed. Rodney Needham, 3-31. Chicago: University of Chicago Press. 
Jung, Carl Gustav. 1968. The Collected Works of C. G. Jung Volume 9, Part I: The Archetypes and the Collective Unconscious, $2^{\text {nd }}$ edition. Translated by R. F. C. Hull. London: Routledge and Kegan Paul.

Jung, Carl Gustav. 1968. The Collected Works of C. G. Jung Volume 9, Part II: AION, $2^{\text {nd }}$ edition. Translated by R. F. C. Hull. London: Routledge and Kegan Paul.

Jung, Carl Gustav. 1969. The Collected Works of C. G. Jung Volume 11: Psychology and Religion, $2^{\text {nd }}$ edition. Translated by R. F. C. Hull. London: Routledge and Kegan Paul.

Kozlovic, Anton Karl. 2002. Superman as Christ-Figure: The American Pop Culture Movie Messiah. Journal of Religion and Film 6, no.1 (April), http://www.unomaha.edu/jrf/superman.htm (accessed February 13 2010).

Levi-Strauss, Claude. 1980. Myth and Meaning. London: Routledge.

Levy-Bruhl, Lucien. 1926. How Natives Think. Translated by Lilian A. Clare. London: Allen and Unwin.

Mauss, Marcel. 1985. A Category of the Human Mind: the notion of person; the notion of self. In The Category of Person, ed. Michael Carrithers, Steven Collins, and Steven Lukes, 125. Cambridge: Cambridge UP.

McDowell, John C. 2007. The Gospel According to Star Wars: Faith, Hope, and the Force. Louisville and London: Westminster John Knox Press.

Mitchell, Lee Clark. 1996. Westerns: Making the Man in Fiction and Film. Chicago and London: The University of Chicago Press.

Otto, Rudolf. 1958. The Idea of the Holy. Translated by John W. Harvey. London: Oxford UP.

Parrish, Tim. 2004. Jesus on the Mainline: Lou Reed and Denis Johnson's Jesus' Son.

Journal of Religion and Popular Culture 7, (Summer 2004), http://www.usask.ca/relst/jrpc/art7-jesusson.html (accessed 13 February 2010).

Parry, Jonathan. 1986. The Gift, the Indian Gift and the 'Indian Gift'. MAN 21: 453-473.

Pelikan, Jaroslav. 1985. Jesus through the Centuries: His Place in the History of Culture. London: Yale UP.

Robinson, Jeremy Mark. 2007. The Sacred Cinema of Andrei Tarkovski. Kent: Crescent Moon.

Rohdie, Sam. 1995. The Passion of Pier Paolo Pasolini. London: BFI.

Turner, Victor and Edith. 1978. Image and Pilgrimage in Christian Culture. Oxford: Basil Blackwell. 
Wakeman, John (ed). 1987. World Film Directors Volume 2, 1945-1985. New York: HW Wilson.

Walsh, Richard. 2008. The Passion as Horror Film: St Mel of the Cross. Journal of Religion and Popular Culture 20, (Fall 2008), http://www.usask.ca/relst/jrpc/art20-

passionashorror.html (accessed 13 February 2010).

Weber, Max. 1968. The Sociology of Charismatic Authority. In Max Weber: On Charisma and Institution Building, ed. Shmuel N. Eisenstadt, 18-27. Chicago: The University of Chicago Press.

Wood, Robin. 1967. Arthur Penn. London : Studio Vista. 
Reproduced with permission of the copyright owner. Further reproduction prohibited without permission. 